http://journal.nafo.int

J. Northw. Atl. Fish. Sci., Vol. 6: 165-171

\title{
Parasitic Fauna of American Plaice (Hippoglossoides platessoides) from the Northwest Atlantic
}

\author{
A. V. Zubchenko \\ Polar Research Institute of Marine Fisheries and Oceanography (PINRO) \\ 6 Knipovich Street, 183763, Murmansk, USSR
}

\begin{abstract}
American plaice (Hippoglossoides platessoides (Fabricius, 1780)) from six offshore areas of the Labrador-Newfoundland region (Hamilton Bank, Funk Island Bank, Flemish Cap, and the northern, southeastern and southwestern slopes of the Grand Bank) were examined for internal parasites. Twenty species of parasites belonging to six major taxonomic groups were found and identified: 4 Protozoa, 2 Cestoidea, 8 Trematoda, 4 Nematoda, 1 Acanthocephala, and 1 Crustacea. Differences in species composition and degree of infestation indicated that the different populations of American plaice were infested with parasite species which are peculiar to their geographic origin.
\end{abstract}

\section{Introduction}

Investigations of the parasitic fauna of fishes provide valuable information on the ecological aspects of the species being studied, particularly with respect to their feeding behaviour and their role in the "parasitehost" cycle. In the case of American plaice (Hippoglossoides platessoides) of the Northwest Atlantic, most aspects of the biology have been generally wellstudied (e.g. Huntsman, 1918; Templeman, 1953; Pitt, 1963, 1966, 1969, 1973, 1976; Lux, 1970; Nevinsky and Serebryakov, 1973), and the parasitic fauna of this species in the Northwest Atlantic have been documented by many authors (Table 1). This list of 45 species of parasites of American plaice from various sources comprises 8 species of Protozoa, 2 of Cestoidea, 21 of Trematoda, 8 of Nematoda, 3 of Acanthocephala, and 3 of Crustacea.

Much of the existing information on parasites of American plaice deals mainly with systematics. In this paper, data on the parasitic fauna of the species from various parts of the Northwest Atlantic are presented and the ecological implications are considered.

\section{Materials and Methods}

Samples of American plaice were collected in June-July 1978 from six areas of the LabradorNewfoundland region, i.e. Hamilton Bank, Funk Island Bank, northern, southeastern and southwestern slopes of Grand Bank, and Flemish Cap (Fig. 1). A total of 143 specimens were examined by the method of complete parasitological dissection (Dogel, 1933). Species identification of the parasites were made by scientists of the parasitological laboratories of the Polar Institute of
Marine Fisheries and Oceanography, Murmansk (PINRO), and the Atlantic Research Institute of Marine Fisheries and Oceanography, Kaliningrad (AtlantNIRO). The data are presented in terms of rate of infestation (percentage of infested fish) and mean intensity of infestation (mean number of parasites per fish).

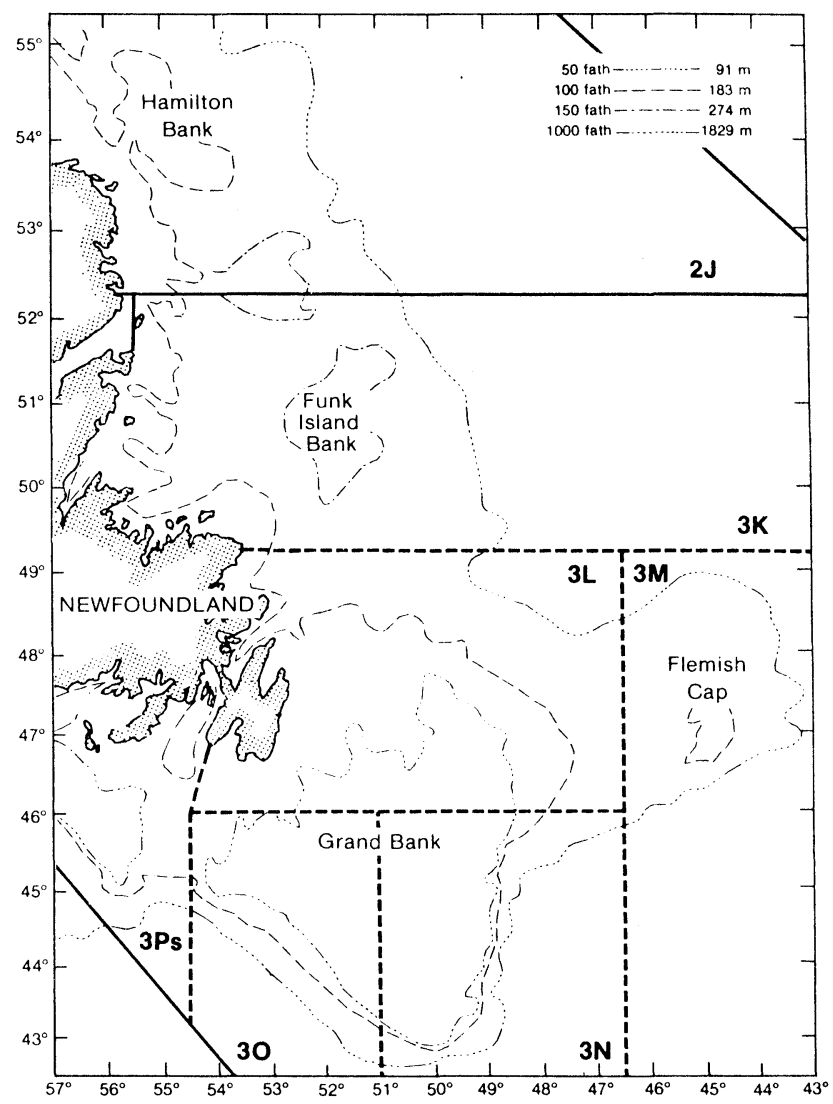

Fig. 1. Labrador-Newfoundland region showing the banks where the American plaice samples were obtained. 
TABLE 1. Some reported parasites of American plaice in the Northwest Atlantic.

\begin{tabular}{|c|c|}
\hline Species & Literature sources \\
\hline \multicolumn{2}{|l|}{ Protozoa } \\
\hline Ceratomyxa drepanopsettae Awerinzew, 1908 & Zubchenko (1980) \\
\hline Cryptobia bullocki Strout, 1965 & Daily (1978) \\
\hline Haemohormidium terraenovae So, 1972 & So $(1972)$ \\
\hline Haemohormidium sp. & Laird and Bullock (1969) \\
\hline Myxidium sphaericum Thelohan, 1895 & Zubchenko (1980) \\
\hline Ortholinea divergens (Thelohan, 1895) & Zubchenko (1980) \\
\hline $\begin{array}{l}\text { Schulmania aenigmatosa Kovaljova, Zubtschenko and } \\
\text { Krasin, } 1983\end{array}$ & $\begin{array}{l}\text { Zubchenko (1980) as Myxoproteus sp., Kovaljova et al. } \\
(1983)\end{array}$ \\
\hline Trypanosoma murmanensis Nikitin, 1927 & Khan (1977) \\
\hline
\end{tabular}

\section{Cestoidea}

Bothrimonus sturionis Duvernoy, 1842

Syn: Diplocotyle olrikii Krabbe, 1874

Scolex pleuronectis O. F. Muller, 1788

Ronald (1958b)

Ronald (1958b), Zubchenko (1980)

\section{Trematoda}

Anisoporus manteri Humminen and Cable, 1940

Aporocotyle simplex Odhner, 1900

Brachyphallus crenatus (Rudolphi, 1802)

Cryptocotyle lingua (Creplin, 1825)

Derogenes varicus (O. F. Muller, 1784)

Diphterostomum microacetabulum (Shulman-Alborva, 1952)

Genolinea laticauda Manter, 1925

Gonocerca macroformis Wolfgang and Myers, 1954

Hemiurus levinseni Odhner, 1905

Hemiurus sp.

Lecithaster gibbosus (Rudolphi, 1802)

Otodistomum veliporum (Creplin, 1837)

Podocotyle atomon (Rudolphi, 1802)

Progonus muelleri (Levinsen, 1881)

Syn: Distoma muelleri Levinsen, 1881

Genarches muelleri (Levinsen, 1881)

Genarchopsis muelleri (Levinsen, 1881)

Prosorhynchus squamatus Odhner, 1905

Steganoderma formosum Stafford, 1904

Syn: Nordostrema messjatzevi (Issaitschikov, 1928)

Stenakron vetustum Stafford, 1904

Syn: Rhodotrema problematicum Issaitschikov, 1928

Stenakron problematicum (Issaitschikov, 1928)

Rhodotrema quadrilobata Bazikalova, 1932

Steringotrema quadrilobatum (Bazikalova, 1932)

Stenakron quadrilobatum (Bazikalova, 1932)

Stephanostomum baccatum (Nicoll, 1907)

Steringophorus furciger (Olsson, 1867)

Syn: Distomum furcigerum Olsson, 1867

Leioderma furcigerum (Olsson, 1867)

Fellodistomum furcigerum (Olsson, 1867) 
TABLE 1. (continued).

\begin{tabular}{|c|c|}
\hline Species & Literature sources \\
\hline $\begin{array}{l}\text { Steringotrema ovacutum (Lebour, 1908) } \\
\text { Syn: Steringophorus ovacutus Lebour, 1908 } \\
\text { Rhodotrema ovacutum (Lebour, 1908) } \\
\text { Stenakron ovacutus (Lebour, 1908) }\end{array}$ & Scott (1975a, 1975b, 1982), Bray (1979), Zubchenko (1980) \\
\hline $\begin{array}{l}\text { Zoogonides viviparus (Olsson, 1868) } \\
\text { Nematoda }\end{array}$ & Scott (1975a, 1975b), Zubchenko (1980) \\
\hline Anisakinae gen. sp. (larva) & Ronald (1963) \\
\hline Anisakis sp. (larvae) & Templeman et al. (1957), Zubchenko (1980) \\
\hline Capillaris kabatai Inglis et Coles, 1963 & Zubchenko (1980) \\
\hline Contracaecum sp. & Ronald (1963) \\
\hline Nematoda gen. sp. & Huntsman (1918) \\
\hline $\begin{array}{l}\text { Phocanema decipiens (Krabbe, 1878) } \\
\text { Syn: Porrocaecum decipiens (Krabbe, 1878) } \\
\text { Terranova decipiens (Krabbe, 1878) }\end{array}$ & $\begin{array}{l}\text { Scott }(1950,1953,1954), \text { Myers (1960), Scott and Black } \\
\text { (1960), Zubchenko (1980) }\end{array}$ \\
\hline $\begin{array}{l}\text { Phocanema sp. } \\
\text { Syn: Porrocaecum sp. } \\
\quad \text { Terranova sp. }\end{array}$ & Templeman et al. (1957), Ronald (1963) \\
\hline $\begin{array}{l}\text { Thynnascaris adunca (Rudolphi, 1802) } \\
\text { Syn: Contracaecum aduncum (Rudolphi, 1802) } \\
\text { Contracaecum gadi (O. F. Muller, 1777) }\end{array}$ & Ronald (1963), Zubchenko (1980) \\
\hline \multicolumn{2}{|l|}{ Acanthocephala } \\
\hline Corynosoma sp. & Ronald (1963) \\
\hline Echinorhynchus gadi (O. F. Muller, 1776) & Ronald (1963) \\
\hline Echinorhynchus laurentianus Ronald, 1957 & Roinald (1957, 1963) \\
\hline \multicolumn{2}{|l|}{ Crustacea } \\
\hline $\begin{array}{l}\text { Acanthochondria cornuta (O. F. Muller, 1776) } \\
\text { Syn: Acanthochondria flurae (Kroyer, 1863) }\end{array}$ & $\begin{array}{l}\text { Bere (1930), Wilson (1932), Leigh-Sharpe (1933), Ronald } \\
\text { (1958a), Zubchenko (1980) }\end{array}$ \\
\hline Argulus megalops Smith, 1874 & Wilson (1905) \\
\hline Lernaeocera branchialis (Linnaeus, 1767) & Templeman et al., (1976) \\
\hline
\end{tabular}

\section{Results}

The parasitological investigation of 143 American plaice yielded 20 species of parasites (Table 2) which belong to 6 major taxonomic groups: Protozoa (4), Cestoidea (2), Trematoda (8), Nematoda (4), Acanthocephala (1), and Crustacea (1).

\section{Hamilton Bank}

Sixteen species of parasites were found in the 24 specimens that were examined. Ceratomyxa drepanopsettae was the most significant of the parasites with a direct developmental cycle. Of the parasites with a complex developmental cycle, the fish were found to be rather heavily infested with Aporocotyle simplex, and moderately with Steringotrema ovacutumn and Echinorhynchus gadi, which were probably acquired by the fish from feeding on infested gastropods, bottom copepods and amphipods, implying that these animals form a significant part of the diet of American plaice. Infestation was much less significant for other parasites with complex developmental cycles, which are associated with benthic animals (Diphterostomum microacetabulum, Genolinea laticauda, Stenakron vetustum, Steringophorus furciger) and with plankton (Anisakis simplex, Lecithaster gibbosus, Scolex pleuronectis, Thynnascaris adunca).

\section{Funk Island Bank}

Eleven species of parasites were found in the 15 specimens that were examined. Infestation of the fish with Ceratomyxa drepanopsettae in this area was somewhat lower than on Hamilton Bank, whereas the incidence of Aporocotyle simplex and Steringotrema ovacutum was notably higher, indicating a close association of American plaice with the bottom and the important role of gastropods in the feeding regime. However, infestation with Scolex pleuronectis larvae 
TABLE 2. Parasitic fauna of American plaice in six areas of the Northwest Atlantic from sampling in June-July 1978

\begin{tabular}{|c|c|c|c|c|c|c|c|c|c|c|c|c|}
\hline \multirow[b]{2}{*}{ Parasite } & \multicolumn{2}{|c|}{ Hamilton Bank } & \multicolumn{2}{|c|}{ Funk Island Bank } & \multicolumn{2}{|c|}{ N Grand Bank } & \multicolumn{2}{|c|}{ SW Grand Bank } & \multicolumn{2}{|c|}{ SE Grand Bank } & \multicolumn{2}{|c|}{ Flemish Cap } \\
\hline & $\begin{array}{c}\text { Specimens } \\
\text { infested } \\
\% \\
\end{array}$ & $\begin{array}{l}\text { Mean } \\
\text { infes- } \\
\text { tation }\end{array}$ & $\begin{array}{c}\text { Specimens } \\
\text { infested } \\
\% \\
\end{array}$ & $\begin{array}{l}\text { Mean } \\
\text { infes- } \\
\text { tation }\end{array}$ & $\begin{array}{c}\text { Specimens } \\
\text { infested } \\
\% \\
\end{array}$ & $\begin{array}{l}\text { Mean } \\
\text { infes- } \\
\text { tation }\end{array}$ & $\begin{array}{c}\text { Specimens } \\
\text { infested } \\
\%\end{array}$ & $\begin{array}{l}\text { Mean } \\
\text { infes- } \\
\text { tation }\end{array}$ & $\begin{array}{c}\text { Specimens } \\
\text { infested } \\
\% \\
\end{array}$ & $\begin{array}{l}\text { Mean } \\
\text { infes- } \\
\text { tation }\end{array}$ & $\begin{array}{c}\text { Specimens } \\
\text { infested } \\
\% \\
\end{array}$ & $\begin{array}{l}\text { Mean } \\
\text { infes- } \\
\text { tation }\end{array}$ \\
\hline \multicolumn{13}{|l|}{ Protozoa } \\
\hline Ceratomyxa drepanopsettae & 95.8 & + & 73.3 & + & 63.3 & + & 70.0 & + & 55.2 & + & 93.3 & + \\
\hline Myxidium sphaericum & 29.2 & + & 33.3 & + & 10.0 & + & 13.3 & + & 10.3 & + & 53.3 & + \\
\hline Ortholinea divergens & - & - & - & - & - & - & - & - & - & - & 20.0 & + \\
\hline Schulmania aenigmatosa & 29.2 & + & - & - & - & - & - & - & - & - & -- & - \\
\hline \multicolumn{13}{|l|}{ Cestoidea } \\
\hline Grillotia erinaceus (larvae) & - & - & - & - & - & - & - & - & 10.3 & 0.1 & 66.7 & 5.1 \\
\hline Scolex pleuronectis (larvae) & 4.2 & 0.1 & 40.0 & 4.5 & 16.7 & 0.7 & 3.3 & 0.1 & 24.1 & 0.6 & 33.3 & 2.3 \\
\hline \multicolumn{13}{|l|}{ Trematoda } \\
\hline Aporocotyle simplex & 41.7 & 0.9 & 66.7 & 1.3 & 6.7 & 0.1 & 10.0 & 0.1 & 13.8 & 0.1 & - & - \\
\hline Derogenes varicus & - & - & - & - & 6.7 & 0.1 & - & - & 6.9 & 0.1 & 20.0 & 0.3 \\
\hline Diphterostomum microacetabulum & 4.2 & 0.7 & - & - & - & - & - & - & - & - & - & - \\
\hline Genolinea laticauda & 12.5 & 0.3 & 26.7 & 0.4 & - & - & - & - & 6.9 & 0.1 & - & - \\
\hline Lecithaster gibbosus & 8.4 & 0.1 & - & - & - & - & - & - & - & - & 26.7 & 0.3 \\
\hline Stenakron vestustum & 4.2 & 0.0 & 6.7 & 0.2 & - & - & 36.7 & 0.8 & 10.3 & 9.9 & - & - \\
\hline Steringophorus furciger & 4.2 & 0.6 & 20.0 & 2.3 & 26.7 & 1.0 & 23.3 & 1.3 & 34.5 & 2.5 & 86.7 & 18.7 \\
\hline Steringotrema ovacutum & 37.5 & 2.1 & 73.3 & 3.0 & 56.7 & 7.0 & 46.7 & 14.0 & 44.8 & 9.2 & 60.0 & 8.6 \\
\hline \multicolumn{13}{|l|}{ Nematoda } \\
\hline Anisakis simplex (larvae) & 4.2 & 0.0 & - & - & 6.7 & 0.1 & 33.3 & 0.4 & 10.3 & 0.1 & 46.6 & 0.3 \\
\hline Ascaropis arctica & - & - & - & - & 3.3 & 0.2 & 10.0 & 0.1 & - & - & - & - \\
\hline Phocanema decipiens (larvae) & 25.0 & 0.5 & 13.3 & 0.1 & 36.7 & 2.1 & 6.7 & 0.1 & 10.3 & 0.1 & 26.7 & 0.5 \\
\hline Thynnascaris adunca (larvae) & 16.7 & 0.1 & 13.3 & 0.1 & 13.3 & 0.3 & 6.7 & 0.1 & 17.2 & 0.3 & 86.7 & 5.3 \\
\hline \multicolumn{13}{|l|}{ Acanthocephala } \\
\hline Echinorhynchus gadi & 54.2 & 3.5 & 6.7 & 0.1 & - & - & 6.7 & 0.1 & 20.7 & 0.3 & 53.3 & 3.5 \\
\hline \multicolumn{13}{|l|}{ Crustacea } \\
\hline Acanthochondria cornuta & 4.2 & 0.0 & - & - & - & - & - & - & - & - & - & - \\
\hline Number of fish examined & 24 & & 15 & & 30 & & 30 & & 29 & & 15 & \\
\hline
\end{tabular}

indicates significant association with planktonic organisms.

\section{Flemish Cap}

Fourteen species of parasites were found in the 15 specimens that were examined. In addition to heavy infestation with Ceratomyxa drepanopsettae, which is characteristic of most flatfishes, the American plaice from this area were more heavily infested with Myxidium sphaericum than those from any other area. Moderate to heavy infestation with parasites whose developmental cycles involve planktonic organisms included Anisakis simplex, Derogenes varicus, Grillotia erinaceus, Lecithaster gibbosus, and Thynnascaris adunca. Steringophorus furciger and Echinorhynchus gadi are associated with benthic animals, and they are acquired by American plaice during feeding on bivalve molluscs and amphipods.

\section{Northern slope of Grand Bank}

Eleven species of parasites were found in the 30 specimens that were examined. These fish were rather heavily infested with Ceratomyxa drepanopsettae and Steringotrema ovacutum, whose developmental cycles are associated with benthic organisms. Gas- tropods (intermediate hosts of these two parasites) and amphipods (intermediate hosts of Phocanema decipiens) are evidently the major prey of American plaice in this area.

\section{Southwestern slope of Grand Bank}

Twelve species of parasites were found in the 30 specimens that were examined. In addition to rather heavy infestation of American plaice with Ceratomyxa drepanopsettae, the fish were moderately infested with Anisakis simplex, Stenakron vetustum, and Steringotrema ovacutum, which have a complex developmental cycle. Gastropods, decapods and various pelagic animals are the intermediate hosts of these parasites.

\section{Southeastern slope of Grand Bank}

Fourteen species of parasites were found in the 29 specimens that were examined. Infestation with Ceratomyxa drepanopsettae in this area was lower than in any other area. Of the parasites with a complex developmental cycle, the most significant were Steringotrema ovacutum and Steringophorus furciger, whose intermediate hosts are gastropod and bivalve molluscs, which evidently are important to the feeding regime of American plaice. 


\section{Discussion}

Comparison of the parasitic fauna of American plaice from the various areas showed notable differences in both the specific composition of parasites and the degree of infestation, due possibly to differences in the habitats and feeding preferences of the fish. Quantitative differences in infestation were most pronounced in fish from Hamilton Bank, Flemish Cap and Funk Island Bank. The comparatively high levels of infestation of fish from Hamilton Bank with Aporocotyle simplex and Echinorhynchus gadi were probably due to an abundance of intermediate hosts in the shallow depths and close association of American plaice with the bottom fauna. Aporocotyle simplex was not found on Flemish Cap where the fish inhabit greater depths. In contrast to the situation on Hamilton Bank, infestation of Flemish Cap fish with Anisakis simplex, Grillotia erinaceus, Myxidium sphaericum, Scolex pleuronectis, Steringophorus furciger, Steringotrema ovacutum and Thynnascaris adunca was much higher. Some of these parasites (Anisakis simplex, Grillotia erinaceus and Thynnascaris adunca) are probably acquired by American plaice through consumption of plankton and nektobenthos rather than from eating small fish. The fish specimens from Funk Island Bank were characterized by comparatively high infestation with Scolex pleuronectis, Aporocotyle simplex and Steringotrema ovacutum.

Differences in infestation of fish from the Grand Bank slopes were less pronounced than among other areas, except for the high infestation with Stenakron vetustum on the southwestern slope and with Phocanema decipiens on the northern slope. Echinorhynchus gadi, which occurred in other slope areas, was not found in fish from the northern slope, and Ascarophis arctica, which occurred on the other slopes of Grand Bank, was not found on the southeastern slope. In general, the infestation of American plaice from the Grand Bank with Ceratomyxa drepanopsettae, Myxidium sphaericum and Aporocotyle simplex was lower than in the other areas, apart from the absence of Aporocotyle simplex on Flemish Cap.

It is noteworthy that Schulmania aenigmatosa, Diphterostomum microacetabulum and Acanthochondria cornuta were found only in fish from Hamilton Bank. In an earlier paper (Zubchenko, 1980), the first two parasites were reported as Myxoproteus sp. and Trematoda gen. sp. respectively, and the American plaice in which they were found were from the Labrador area. Although Zubchenko (1980) reported Ortholinea divergens as a parasite of American plaice off Labrador, it was found only in fish from Flemish Cap during the present study. This parasite is commonly found in Greenland halibut (Reinhardtius hippoglossoides) which generally inhabit much greater depths than American plaice, although there may be slight overlap in the distributions of the two flatfishes along the slopes of the continental Shelf. Schulmania aenigmatosa, and Acanthochondria cornuta are typical parasites of flatfish species, but Diphterostomum microacetabulum is characteristic of wolffishes (Anarhichas sp.). According to Chubrik (1966) and Zelikman (1966), possible intermediate hosts of these parasites are the gastropods Cnoba aculeus, Buccinum finmarchianum and Sipho is/andicus, which live in littoral and epicontinental zones, indicating a possible link between American plaice of Hamilton Bank and coastal waters.

The foregoing aspects of American plaice parasitism and ecology lead to some conclusions about the intraspecific structure of populations in the surveyed areas. The populations of Hamilton Bank, Funk Island Bank, Flemish Cap and Grand Bank are geographically isolated, due to presence of deepwater channels which prevent significant movement of fish from one bank to the other. Thus, the parasitological data confirmed the conclusions of Pitt $(1963,1969$, MS 1975), which were based on differences in meristic characters and the results of tagging experiments. The concept of ecological isolation is quite feasible, because spawning of American plaice occurs in virtually all parts of its distributional area (Pitt, 1966). Although the southern populations are not genetically isolated from the northern ones, because eggs and larvae from the northern areas are transported southward by the Labrador Current (Nevinsky and Serebryakov, 1973; Pitt, MS 1975), the intermixing of juveniles and adults among areas is low enough to consider the fish on Hamilton Bank, Funk Island Bank, Grand Bank and Flemish Cap as separate populations.

The parasitological studies showed no pronounced differences in infestation of American plaice from the three slopes of the Grand Bank, although Pitt (1969, MS 1975) noted insignificant migrations of fish within each area and suggested that there were several local populations throughout the Grand Bank region. Although some parasitological characteristics, such as the presence of certain parasites (usually low infestation) in fish from one or two slopes and their absence from the other slopes of the Grand Bank, indicated the possible existence of local groups, the lack of significant isolation is indicated by the almost equal representation of parasites (Ceratomyxa drepanopsettae and Steringotrema furciger) with the highest infestation rates. No parasites, which are uncommon to American plaice but are characteristic of a particular ecological niche (such as Ortholina divergens on Flemish Cap), were found in fish from the Grand Bank slopes. The apparent lack of significant ecological isolation of American plaice on different parts of the Grand Bank is due probably to the existence of adequate living conditions throughout the region and the lack of physical barriers. 


\section{References}

BERE, R. 1930. The parasitic copepods of the fish of the Passamaquoddy region. Contrib. Can. Biol. (New Ser.), 5: 423-430.

BRAY, R. A. 1979. Digenea in marine fishes from the eastern seaboard of Canada. J. Nat. Hist., 13: 399-431.

CHUBRIK, G. K. 1966. Fauna and ecology of trematode larvae from molluscs in the Barents and White Seas. In: Life cycles of parasitic worms of the northern seas ( $p$. 78-166), Nauka Press, Moscow, 168 p.

DAILY, D. D. 1978. Marine fish hematozoa from Maine. J. Parasitol., 64: 361-362.

DOGEL, V. A. 1933. Fish parasitology investigation problems (methods and problems of ichthyoparasitological investigations). Trudy Len. Obshchestva Estestvoispytatelei, 62(2): 247-268.

HUNNINEN, A. V., and R. M. CABLE. 1940. Studies on the life history of a new species of Anisoporus (Trematoda, Allocreadiidae). J. Parasitol., 26(6, suppl.): 33 p.

HUNTSMAN, A. G. 1918. The Canadian plaice. Bull. Biol. Board Can., 1: $32 \mathrm{p}$.

KHAN, R. A. 1977 . Susceptibility of marine fish to trypanosomes. Can. J. Zool., 55: 1235-1241.

KOVALJOVA, A. A., A. V. ZUBCHENKO, and V. K. KRASIN. 1983. Foundation of a new myxosporidean family (Protozoa, Myxosporidia) with a description of two new genera. Parazitologiya, 17(3): 195-202.

LAIRD, M. and W. BULLOCK. 1969. Marine fish haematozoa from New Brunswick and New England. J. Fish. Res. Board Can., 26: 1075-1102.

LEIGH-SHARPE, W. H. 1933. A list of British fishes with their - characteristic parasitic Copepoda. Parasitology, 25(1): 109-112.

LUX, F. E. 1970. Note on growth of American palice, Hippoglossoides platessoides (Fabr.) in ICNAF Subarea 5. ICNAF Res. Bull., 7: 5-7.

MANTER, H. W. 1947. The digenetic trematodes of marine fishes of Tortugas, Florida. Amer. Midl. Nat., 38: 257-416.

MYERS, B. J. 1960. On the morphology and life history of Phocanema decipiens (Krabbe, 1878) (Nematoda, Anisakidae). Can. J. Zool., 38: 331-344.

NEVINSKY, M. M. and V. P. SEREBRYAKOV. 1973. American plaice, Hippoglossides platessoides platessoides Fabr., spawning in the Northwest Atlantic. ICNAF Res. Bull., 10: 23-36.

PITT, T. K. 1963. Vertebral numbers of American plaice, Hippoglossoides platessoides (Fabricius) in the Northwest Atlantic. J. Fish. Res. Board Can., 20: 1159-1181.

1966. Sexual maturity and spawning of the American plaice, Hippoglossoides platessoides (Fabricius), from Newfoundland and Grand Bank areas. J. Fish. Res. Board Can., 23: 651-671.

1969. Migrations of American plaice on the Grand Bank and in St. Mary's Bay, 1954, 1959 and 1961. J. Fish. Res. Board Can., 26: 1301-1319.

1973. Assessment of American plaice stocks on the Grand Bank, ICNAF Divisions $3 \mathrm{~L}$ and $3 \mathrm{~N}$. ICNAF Res. Bull., 10: 63-77.

MS 1975. The delineation of American plaice stocks with special reference to ICNAF Divisions 3LNO. ICNAF Res. Doc., No. 52, Serial No. 3531, 10 p.

1976. Food of yellowtail flounder on the Grand Bank and a comparison with American plaice. ICNAF Res. Bull., 12: 23-27.
RADULESCU, I. 1969. Contributions to the knowledge of the fish parasites from the Atlantic Ocean. Bull. Inst. Ceret. si Project. Pisc., 28(4): 76-82.

RONALD, K. 1957. The metazoan parasites of the Heterosomata of the Gulf of St. Lawrence. I. Echinorhynchus laurentianus sp. nov. (Acanthocephala, Echinorhynchidae). Can. J. Zool., 35: 437-439.

1958a. The metazoan parasites of the Heterosomata of the Gulf of St. Lawrence. III. Copepoda. Can. J. Zool., 36: $1-6$.

$1958 \mathrm{~b}$. The metazoan parasites of the Heterosomata of the Gulf of St. Lawrence. IV. Cestoda. Can. J. Zool., 36: 429-434.

1960. The metazoan parasites of the Heterosomata of the Gulf of St. Lawrence. VI. Digenea. Can. J. Zool., 38: 923-937.

1963. The metazoan parsites of the Heterosomata of the Gulf of St. Lawrence. VII. Nematoda and Acanthocephala. Can. J. Zool., 41: 15-21.

SCOTT, D. M. 1950. A preliminary report of the codworm investigations. Fish. Res. Board Can. Prog. Rep. Atl. Coast Sta., 48: 10-12.

1953. Experiments with the harbour seal, Phoca vitulina, a definitive host of a marine nematode, Porrocaecum decipiens. J. Fish. Res. Board Can., 10: 539-547.

1954. Experimental infection of Atlantic cod with a larval marine nematode from smelt. J. Fish. Res. Board Can., 11: 894-900.

SCOTT, D. M., and W. F. BLACK. 1960. Studies on the lifehistory of the ascarid Porrocaecum decipiens in the Bras d'Or Lakes, Nova Scotia, Canada. J. Fish. Res. Board Can., 17: 763-774.

SCOTT, J. S. 1975a. Incidence of trematode parasites of American plaice (Hippoglossoides platessoides) of the Scotian Shelf and Gulf of St. Lawrence in relation to fish length and food. J. Fish. Res. Board Can., 32: 479-483.

$1975 \mathrm{~b}$. Geographic variation in incidence of trematode parasites of American plaice (Hippoglossoides platessoides) in the Northwest Atlantic. J. Fish. Res. Board Can., 32: 547-550.

1982. Digenean parasite communities in flatfishes of the Scotian Shelf and southern Gulf of St. Lawrence. Can. J. Zool., 60: 2804-2811.

SO, B. K. 1972. Marine fish haematozoa from Newfoundland waters. Can. J. Zool., 50: 543-554.

STAFFORD, J. 1904. Trematodes from Canadian fishes. Zool. Anz., 27: 481-495.

1907. Preliminary report on the trematodes of Canadian marine fishes. Contrib. Can. Biol., 1902-1905: 91-94.

TEMPLEMAN, W. 1953. Knowledge of division of stocks of cod, haddock, redfish, and American plaice in Subareas 2 and 3 of the Northwest Atlantic Convention Area. ICNAF Ann. Proc., 3: 62-66.

TEMPLEMAN, W., V. M. HODDER, and A. M. FLEMING. 1976. Infection of lumpfish (Cyclopterus lumpus) with larvae and of Atlantic cod (Gadus morhua) with adults of the copepod Lernaeocera branchialis in and adjacent to the Newfoundland larea, and inferences therefrom on inshore-offshore migrations of cod. J. Fish. Res. Board Can., 33: 711-731.

TEMPLEMAN, W., H. J. SQUIRES, and A. M. FLEMING. 1957. Nematodes in the fillets of cod and other fishes in Newfoundland and neighbouring areas. J. Fish. Res. Board Can., 14: 831-897. 
WILSON, C. B. 1905. The fish parasites of the genus Argulus found in the Woods Hole region. Bull. U.S. Bur. Fish., 24: 115-131.

1932. The copepods of the Woods Hole region, Massachusetts. Bull. U.S. Nat. Mus., 158: 635 p.

WOLFGANG, R. W. 1954. Studies of the trematode Stephanostomum baccatum (Nicoll, 1907). I. The distribution of the metacercaria in eastern Canadian flounders. J. Fish. Res. Board Can., 11: 954-962.

1955. Studies of the trematode Stephanostomum baccatum (Nicoll, 1907). III. Its life cycle. Can. J. Zool., 33:
113-128.

WOLFGANG, R. W., and B. J. MYERS. 1954. Gonocerca macroformis sp. nov. (Derogenetinae, Hemiuridae) from the ovary of the cod. Can. J. Zool., 32: 25-29.

ZELIKMAN, E. A. 1966. Some ecological-parasitological relationships in the littoral of the northern part of the Kandalaksha Bay. In Life cycles of parasitic worms of the northern seas (p. 7-77), Nauka Press, Moscow, 168 p.

ZUBCHENKO, A. V. 1980. Parasitic fauna of Anarhichadidae and Pleuronectidae familes of fish in the Northwest Atlantic. ICNAF Sel. Papers, 6: 41-46. 
